\title{
A systematic review of Bacterial foodborne outbreaks related to red meat and meat products
}

2Department of Food Hygiene and Food Technology, Faculty of Veterinary Medicine, University of León, León, Spain; ${ }^{3}$ nnstitute of Food Science and Technology, University of León, León, Spain; ${ }^{4}$ Norwegian University of Life Sciences, Department of Food Safety and Infection Biology, Oslo, Norway; ${ }^{5}$ University of Twente, Department of Applied Mathematics, Enschede, Netherlands 
Our investigation focused on foodborne outbreaks related to meat and meat products, published in peer-reviewed journals in the period 1980 - 2015. Most of the outbreaks, investigated in this study, were caused by Escherichia coli and Salmonella, causing 33 and 21 outbreaks respectively, mostly in Europe and the United States. In the E. coli outbreaks, the total number of reported cases was 1966, of which 1543 were laboratory confirmed. The number of cases requiring hospitalization was 476 , of whom 233 cases had a hemolytic-uraemic syndrome (HUS), and the reported deaths were 32. All of the E. coli outbreaks, except four, were caused by serovar O157:H7. The other four outbreaks were caused by the following serovars: O111:H8, O26:H11, O111, and O103:H25. Fresh processed meat products were the category most frequently implicated. In the Salmonella outbreaks the total number of all reported cases were 2279, of whom 1891 were laboratory confirmed. The number of reported cases requiring hospitalization was 94 , and seven were reported dead. Regarding Salmonella, eight serovars caused those outbreaks. The most common serovar causing Salmonella-related outbreaks was $S$. Typhimurium. The food category most frequently implicated in those outbreaks was raw cured fermented sausages. Other organisms linked to meat-associated outbreaks, but less frequently reported, were Staphylococcus aureus, Bacillus cereus, Clostridium perfringens, Clostridium botulinum, and Listeria monocytogenes. Issues of the burden of outbreaks, the challenges of comparing global outbreaks, food attribution and how the meat industry works to meet consumer demands while maintaining food safety are discussed. 
Though there has been much progress in food safety measures, foodborne diseases still pose significant public health challenges. Non-typhoid salmonellosis saw a surge in the 1980'ies, Escherichia coli (E. coli) O157:H7 was first identified as a pathogen in 1982, and in the last 30 years a number of infectious agents have been either newly described or newly associated with foodborne transmission (Riley, Remis et al. 1983, Tauxe 1997). Along with new pathogens, an array of new food vehicles have been implicated in recent years, and many emerging zoonotic pathogens have become increasingly resistant to antimicrobial agents (Tauxe 1997).

Our investigation of foodborne outbreaks related to meat products is confined to the period $1980-2015$ and is limited to bacterial foodborne pathogens, as most detected and reported outbreaks are caused by bacterial agents. Though bacterial food-borne agents and their diseases have been well studied in past years and reported cases are on a downward trend, the disease burden remains substantial and throughout the 1990'ies until today three primary foodborne bacterial agents, i.e., Salmonella, Campylobacter and E. coli, have persisted (Newell, Koopmans et al. 2010).

Reports of outbreak investigations provide the most comprehensive data for determining the foods responsible for illnesses (Batz, Doyle et al. 2005), but of course only represent a fraction of the real occurrence. However, attributing all illnesses to specific foods is challenging, as most agents are transmitted through a wide range of foods and linking them to a particular food is rarely possible except during an outbreak (Painter, Hoekstra et al. 2013). One general method for attribution of the human disease burden of foodborne infections to specific sources is the "microbiological approach", which involves isolation of the pathogen from the source and from ill humans (Pires, Evers et al. 2009).

Raw cured fermented sausages are foods whose safety is based on the addition of salt and nitrite, drying, low $\mathrm{pH}$ and water activity $(\mathrm{aw})$, competition from starter cultures, pre-treatment of the meat, addition of antimicrobials, fermentation temperature and storage 
conditions (Bacus 1997, Riordan, Duffy et al. 1998, Heir, Holck et al. 2010, Holck, Axelsson et al. 2011). The recognition of dry 52 fermented sausages as a potential threat to food safety has led some countries to introduce regulations to minimize the risks (Heir, Holck et al. 2010). Yet, several recent reports highlight the significance of fermented meats as a source of outbreaks (Moore 2004). The food industry is challenged by public health authorities to reduce salt $\left(\mathrm{Na}^{+}\right)$content in their products. The question then arising is what is a "safe" reduced salt level. The meat industry has gradually responded to authorities' recommendations, and it is of interest whether outbreaks have been more often linked to low salt products or if there is any indication of more frequent outbreaks in this type of products.

The aims of this study were to review global outbreaks where red meat and meat products were incriminated as a source for outbreaks and their main clinical consequences involved, and thus poultry was not included. In particular, we wanted to illustrate different risks posed from raw cured fermented meats and other main product categories, to better understand causes and to detect epidemiological trends in pathogens and meat products implicated. 
Literature search

65 The primary literature search was undertaken using the Advanced Search Builder provided by PubMed 66 (www.ncbi.nlm.nih.gov/pubmed), Web of Science ${ }^{T M}$ by Thomson Reuters (http://apps.webofknowledge.com) and Google Scholar 67 (https://scholar.google.no/?hl=no).

68 Search settings in Web of Science were "All years" and language "Auto-select". The following search terms were used in Web of 69 Science: Web of Science search, "Language all, years 1980 - 2015: meat, fermented, outbreaks". In total, 77 manuscripts were 70 obtained. PubMed searches resulted in 78 hits, using the above filters, and the following search details:(("meat"[MeSH Terms] OR "meat"[All Fields]) AND fermented[All Fields] AND ("epidemiology"[Subheading] OR "epidemiology"[All Fields] OR "outbreaks"[All Fields] OR "disease outbreaks"[MeSH Terms] OR ("disease"[All Fields] AND "outbreaks"[All Fields]) OR "disease outbreaks"[All Fields])) AND ("1985/01/01"[PDAT] : "2015/12/31"[PDAT]). The search was conducted in October 2015, and a final search and update were conducted in July 2016. Selected manuscripts were then checked for other relevant references not obtained from direct searches. For the purposes of this study, we defined a foodborne disease outbreak as the occurrence of two or more similar illnesses resulting from the ingestion of a common food. Bacterial food-borne outbreaks that were included were those that were published in peer-reviewed journals between January 1, 1980 and December 31, 2015 and were confirmed by laboratory diagnosis.

79 Inclusion criteria

80 In the screening process, we first reviewed titles to check if selected articles were appropriate. Then all abstracts were screened, and

if abstracts were relevant, we checked the full-text article considering the following inclusion criteria: (i) At least two of the cases were 
laboratory confirmed; (ii) The incriminated food was given, (iii) Sufficient data was given on the cases. Exclusion criteria were the following criteria: (i) No sufficient data are given to compare the results and ii) outbreaks due to poultry meats were also excluded. search, out of the 77 results, 13 were further screened and 6 were included. Using the Google Scholar, yielded 39 results that were further screened and 17 of those met the study criteria. Further outbreak studies were screened from the related references.

The outbreak details of all papers meeting our inclusion/ exclusion criteria for etiology and food vehicle were entered into an Excel sheet and checked by two of the authors, before data analysis. Thus, we included all outbreaks reported in peer reviewed publications from 1980-2015, caused by any bacterial enteric pathogen, in which the implicated food item included beef, lamb, pork and meat products thereof.

\section{Entities and variables}

We recorded variables from the entities Outbreak, Cases and Incriminated products. Our database included (i) Outbreak, with variables: Year outbreak, Incriminated meat product, Main reason, Pathogen, Serovar, Country, State, International, Age Minimum, pupura (TTP), Bacteremia/Septicemia, Nausea-vomiting, Abortion, Allergy, Hospitalization, and Death, and (iin)

fat content. 
Meat categories

The meat products linked to outbreaks of disease were classified into the following four categories, as defined in Annex I of Regulation (EC) No 853/2004 (EU Commission 2004):

1. Fresh processed meat products: Hamburgers, barbecue meat and fresh sausages were included in this category.

2. Salted dried meat products: Whole muscle cuts, like ham and bacon, treated with dry salt or a curing solution (pickling), drycured, smoked and/or seasoned. Shoulders and legs of pork are the pieces most commonly cured. Examples of this type of products are dry-cured ham, cecina, jerky, and fenalår. In the European Union legislation, they are known as meat products.

3. Raw cured fermented sausages: The meat can come from beef, veal, pork, lamb, or a combination of these species. Some sausages are made from meat that is cured and smoked before it is minced; most sausages are formed first (mincing, salting), and then cured, smoked, or treated by a combination of these processes. Production of dry and semi-dry sausages requires carefully controlled fermentation and drying. There is a variety of this kind of products including chorizo and salami. The legislation describes those as meat products.

4. Cooked meat products: Cooked ham, frankfurters, bologna, etc. are typical products included in this category. Products such as mortadella, bologna, frankfurters and many loaf types of luncheon meat are made from finely ground meat emulsions. Some cooked sausages are made from meat that is cured, smoked or cooked before it is ground; other sausages are formed first, and then cured, smoked, cooked (in another category) or treated by a combination of these processes. 
The Excel ${ }^{\circledR}$ database of meat-associated outbreaks included information on year of outbreak, median age of patients, agent, serovar, 121 food incriminated, food category, main reason, number of cases, number of cases that were laboratory-confirmed, number of hospitalizations, deaths, and location and cases with HUS for the E. coli related outbreaks. The variables that had enough data to be 123 compared were statistically descriptive using mainly tables and graphs statistics in Exce ${ }^{\circledR}$ or SPSS (IBM SPSS Statistics for Windows, 124 Version 23.0. Armonk, NY: IBM Corp.) 


\section{Results}

The two organisms causing most reported meat-related outbreaks were verotoxin-producing Escherichia coli (VTEC) and Salmonella. The details of the E. coli outbreaks $(n=33)$ is shown in Table 1. The details of the Salmonella outbreaks $(n=21)$ is shown in Tables 2 . In the E. coli outbreaks, the total number of reported cases was 1966, of which $1543(78.4 \%)$ were laboratory confirmed. The number of cases requiring hospitalization was 476 (24.2\%), of whom 233 (48.9\%) cases had a hemolytic-uraemic syndrome (HUS), and the reported deaths were $32(1.6 \%)$. While in the Salmonella outbreaks the total number of all reported cases were 2279 , of whom 1891 (83\%) were laboratory confirmed. The number of reported cases requiring hospitalization was $94(4.1 \%)$, and seven (0.3\%) were reported dead. Other organisms linked to meat-associated outbreaks, but less frequently reported, were Staphylococcus aureus, Bacillus cereus, Clostridium perfringens, Clostridium botulinum, and Listeria monocytogenes.

Outbreaks due to E. coli

In our survey, 16/33 (48.5\%) of the VTEC outbreaks were reported from the USA. Most $(n=29)$ of the outbreaks, were caused by serovar O157:H7 (87.8\%), while the other four outbreaks were caused by the O111:H8, O26:H11, O111, and O103:H25. As shown in Figure 1, fresh processed meat products was the category most frequently implicated, in 17/33 (51.5\%) of the outbreaks. The second meat category most frequently implicated was raw cured fermented sausages, linked to 11/33 (33.3\%) of the outbreaks. As shown in Figure 2, the most extensive outbreak, caused by E. coli O157:H7, with more than 600 cases was in 1992/93, in the USA, and hamburgers were incriminated as the source of infection. The highest number of outbreaks (5) was seen in 2009 as shown in Figure 3. Four of the outbreaks had more than 100 cases. Three had $51-100$ cases, 20 had $10-50$ cases, while six had less than 10 cases.

Table 3 shows the distribution of HUS cases by the total cases within a meat product category and out of the total cases. HUS cases were reported in raw cured fermented sausages (16.4\%), cooked meat products (13.4\%), fresh processed meat (10.3\%), and 
unknown meat products (3.6\%). The corresponding percentage of HUS cases out of all cases was $5.9 \%$ in fresh processed meat, 3.2 in cooked meat products, 2.6 in raw cured fermented sausages, and 0.1 in unknown meat products. In our survey, HUS was diagnosed in at least one patient in $79.4 \%$ of the outbreaks. In six of the outbreaks with E. coli, there were more than 10 cases of HUS in each outbreak. In three of those outbreaks, all the cases developed HUS. Of those, two outbreaks were caused by Raw Cured Fermented Sausages, while fresh processed meats were incriminated in the third outbreak.

\section{Outbreaks caused by Salmonella species}

As shown in Figure 4, in total, there were 8 serovars that caused those outbreaks. The most common serovar causing Salmonellarelated outbreaks was $S$. Typhimurium, involved in $61.9 \%(13 / 21)$ of the total number of outbreaks. Figure 3 shows the time trends which is the number of reported outbreaks per year. There were four outbreaks in 2005, of which the largest outbreak, with 525 cases of infection, occurred in Germany in the same year, where raw minced pork and fermented sausages were implicated, and it was caused by $S$. Bovimorbificans. The meat category most frequently implicated in the outbreaks (10/21) was raw cured fermented sausages (47.6\%). The spectrum of serovars isolated from raw cured fermented sausages was broad, as 5 out of the 8 different reported serovars were involved. Fresh processed meats and cooked meat products were implicated in $23,8 \%$ of the outbreaks. We did not record any Salmonella outbreak in peer-reviewed journals from $2010-2015$.

Outbreaks caused by other bacterial pathogens

There were very few reported red meat related outbreaks caused by other pathogens, other than VTEC and Salmonella. For some pathogens, there are simply too few outbreaks with identified food vehicles to estimate attribution. Regarding outbreaks caused by toxins of $C$. botulinum, an outbreak in Taiwan was attributed to fermented goat meat (Tseng, Tsai et al. 2009) and a special outbreak in Alaska was attributed to fermented beaver tail and paw (CDC 2001). 
Clinical listeriosis mainly occurs in particular at-risk groups: pregnant women, elderly people, immunocompromised people, unborn babies, and neonates (Maertens de Noordhout, Devleesschauwer et al. 2014). Human listeriosis is a relatively rare, but serious zoonotic disease associated with high hospitalization and high lethality rates in these vulnerable populations. Of all the zoonotic diseases under EU surveillance, listeriosis causes one of the most severe human diseases, but few outbreaks are reported each year and very few of them are associated with meat and meat products. Except for one outbreak reported in 2013, related to meat and meat products with 34 cases, listeriosis outbreaks involved two to four cases each, resulting in 51 cases, 11 hospitalizations and 2 deaths (EFSA 2015).

A multistate outbreak of listeriosis was reported in the United States in 1998 that caused illness in 108 persons residing in 24 states and caused 14 deaths and four miscarriages or stillbirths (Graves, Hunter et al. 2005). The outbreak was associated with contaminated hot dogs. In a study in the USA on foods implicated in outbreaks, $(1998-2008)$ it was reported that out of the confirmed outbreaks related to meat, 4/208 (1,9\%) were caused by Bacillus cereus, 71/208 (34,1\%) were due to Clostridium perfringens, and 45/208 $(21,6 \%)$ were due to Staphylococcus aureus (Bennett, Walsh et al. 2013).

Food handling by a food worker after food preparation was mainly involved in Staphylococcus outbreaks, as the organism but not the toxins are usually eliminated by cooking and pasteurization. In contrast to $C$. perfringens and $S$. aureus, $B$. cereus outbreaks were most commonly associated with rice or fried rice dishes (Stewart 2005, Stenfors Arnesen, Fagerlund et al. 2008). 


\section{Discussion}

Out of 9,6 million estimated annual domestically acquired foodborne illnesses in the United States, 1998 - 2008, with known etiology, caused by bacterial, viral, parasitic and chemical agents, 1,174,257 (12.2 \%) were attributed to meat. Out of all foodborne illnesses $(3,645,773)$ due to bacterial agents, in the study, 844,006 (23.2 \%) were attributed to meat (Painter, Hoekstra et al. 2013). In the same study, an estimated 130/862 (15.1\%) deaths each year due to bacterial agents were attributed to meat, and an estimated $5,238 / 35,979(14.6 \%)$ of annual hospitalizations due to bacterial agents were attributed to meat. Among the 839 strong evidence outbreaks of salmonellosis reported by 24 European Union member states in 2013, pig meat and products thereof accounted for 7.7 $\%$, while bovine meat and products thereof were identified as a source vehicle in $3.6 \%$ (EFSA 2015).

In the EU, where the most commonly reported VTEC serovar in 2013 was, as in previous years, O157 (48.9\%) of cases with known serovar and serovar O26 was the second most common in meat (EFSA 2015). This was in agreement with our study as the most commonly isolated serovar was also O157. Between 1983 and 2002, in a study in the USA, of human non-O157 Shiga toxin-producing E. coli (STEC) isolates from persons with sporadic illnesses, the most common serovars were O26 (22\%), O111 (16\%), O103 (12\%), O121 (8\%), O45 (7\%), and O145 (5\%) (Brooks, Sowers et al. 2005). The more frequent isolation of non-O157 STECs has been shown to correlate nicely with the gradual introduction of culture-independent enzyme immunoassay tests in laboratories (Gould, Walsh et al. 2013).

In 2014, 13 of the member states in the EU reported 39 outbreaks where VTEC was reported as the causative agent (excluding waterborne outbreaks). These outbreaks involved 270 cases and 34 hospitalizations, and eight of these outbreaks were caused by VTEC 
0157. Meat and meat products were not incriminated in the strong evidence supported outbreaks, but four outbreaks were categorized originating from "bovine meat and products thereof" in the weak-evidence outbreaks (EFSA 2015). In the same publication, 23 Member states in the EU reported a total of 1,048 food-borne outbreaks (225 strong-evidence, 823 weak-evidence) caused by Salmonella (excluding one strong-evidence water-borne outbreak) (EFSA 2015). These outbreaks involved 9,226 cases, 1,944 hospitalizations, and 14 deaths. Distribution of food vehicles in strong-evidence outbreaks caused by Salmonella in the EU, 2014, was 225 outbreaks ( $9.3 \%$ of the outbreaks) were attributed to pig meat and products thereof, $3.1 \%$ to meat and meat products, 2.7 $\%$ to buffet meats, and $2.2 \%$ to bovine meat and products thereof.

$S$. Typhimurium was the serovar most frequently (40\%) implicated in pigs and pig meat as well as bovine meat in strong-evidence outbreaks reported in the European Union (EFSA 2015). In a study in the United States, thirty serovars caused beef related outbreaks during 1973-2011, with the most common being Typhimurium (16 outbreaks), Newport (15), and Enteritidis (8). This is in agreement with our findings as the most common serovar causing Salmonella-related outbreaks was $S$. Typhimurium. Outbreaks caused by serovars Newport and Typhimurium also accounted for more illnesses and hospitalizations than any other single serovar (Laufer, Grass et al. 2015).

The Listeria outbreak from Canada (Currie, Farber et al. 2015) demonstrated the need for improved listeriosis surveillance, strict control of $L$. monocytogenes in establishments producing ready-to-eat foods, and advice to vulnerable populations and institutions. However, even though being ready-to-eat products, no reported outbreak has been connected to raw cured fermented sausages through all these years. This strongly indicates that bacteriological surveillance for Listeria and corrective actions like retractions or recalls, from these products are not risk-based, e.g. Food safety criteria (EU Commission 2005).

We had to confine the analysis to those variables reported in most outbreaks in our study. This highlights an important gap in the literature. The medical community tends to report on outbreak and case entities but focus very little on characterizing the incriminated 
products. The food science community tends to study the potential growth, survival, or decimation of pathogens under conditions relevant for production and distribution of foods. Similarly, National public health institutes have a long tradition of reporting outbreaks in scientific journals like Eurosurveillance or Morbidity and Mortality Weekly Report (MMWR). National Food Authorities do not have the same tradition, and management of outbreaks and crises tend to stop after governmental actions, like a retraction, recalls, and closure of production premises, take place. The rationale for corrective actions undertaken is seldom peer reviewed. Authorities have paid less attention to quality aspects of foods, and laboratory services are in many countries outsourced. Multidisciplinary competences are needed to draw sound conclusions from outbreak data, and it is our opinion that a deeper and applied understanding of microbiology, processing steps and technological aspects of industrial production is needed, as well as peer-reviewed publishing of risk and event management.

Surveillance systems vary between countries and thereby the likelihood that an outbreak is reported also depends on the country and its reporting systems (Callejon, Rodriguez-Naranjo et al. 2015). Outbreaks were mainly reported from industrialized countries, and apparently represent a bias from available resources or priorities.

It has been reported that the more extensive an outbreak, the more likely it is to represent a major and unusual failure in food safety systems, the more likely it is to have been noticed and thoroughly investigated, and the more likely it is that the vehicle will be identified (Batz, Hoffmann et al. 2012, Callejon, Rodriguez-Naranjo et al. 2015).

Outbreaks from a non-conformant batch or resulting from systematic errors in large food producers are more easily detected in public surveillance systems (Callejon, Rodriguez-Naranjo et al. 2015). From England and Wales only 3 \% of outbreaks reported to national surveillance systems were published in peer-reviewed literature (O'Brien, Gillespie et al. 2006). It is also reported that, when the outbreak size varies by food category, attribution percentages based on a number of cases become skewed towards those foods more likely to cause extensive outbreaks (Batz, Hoffmann et al. 2012). An effect of increased awareness and intensified laboratory testing increases the likelihood of detection. Increased notification rates were observed in the EU in the two consecutive years (EFSA 
2015) also for other serovars than 0157 following the large outbreak caused by VTEC O104:H4 in Europe in 2011 (EFSA 2011 ). Since the large outbreak in 1993, minced meat products have been put at the front of investigators' minds when STEC outbreaks occur, while a lot of other food items have emerged as essential sources or vehicles (Lynch, Tauxe et al. 2009, Heiman, Mody et al. 2015).

Based on calculation of Publication Bias Index (PBI) in the UK, it has been reported that peer-reviewed publications underestimate those outbreaks that are due to red meat and meat products, poultry, fish, egg and egg products while overestimating the impacts of milk and milk products (O'Brien, Gillespie et al. 2006). Hence, the freshly processed meat category, containing big volume products, might be relatively overrepresented among the reported outbreaks.

\section{Methods for source attribution}

There are several methods for attribution of foodborne illnesses to their source. Five basic approaches to source attribution have been reported (Batz, Hoffmann et al. 2012).

We categorized the meats according to the definitions given in the European Union Legislation and found them comprehensive and relevant.

Attribution approaches also differ in their points of attribution, where "point of production" approaches focus on primary food production activities, whereas "point of consumption" approaches, focus on food vehicles that directly lead to exposure (e.g., E. coli 0157 in hamburgers) (Batz, Doyle et al. 2005, Batz, Hoffmann et al. 2012). Primarily, the outbreak papers tended to focus on the point of consumption (case-controls, bacteriological analyses of products), and secondarily the investigation turns at the point of production. Both governmental and industrial risk managers need insight in these investigations beyond the determination of the source of infection. 


\section{Food matrices and pathogen}

The food matrix may affect virulence. In addition, more likely, serious illnesses where patients are hospitalized, are probably more frequently detected and reported. Our results show that the majority of STEC outbreaks were rather small outbreaks compared to Salmonella outbreaks. The median number of cases was 21 for outbreaks caused by E. coli and 58 for Salmonella, respectively. Generally, outbreaks from small food producers are not easily detected as they cannot be easily distinguished from sporadic cases. Geographical or organizational collaboration and exchange of information are crucial for identification of outbreaks and sources of infection when the distribution of patients gets complicated in time or space. Our results indicate that likelihood for detection and notification depends on the severity of disease and not at least the presence of pathognomonic symptoms (HUS) or deviating bacteriological properties (sorbitol fermenting E. coli 0157). Another example illustrating the impact of unusual appearance in the laboratory, was an outbreak caused by a rare Salmonella phagevar (14b) easily distinguished in the laboratory from other $S$. Enteritidis isolates (Guerin, Nygard et al. 2006).

A shift has been observed in the type of beef implicated, from roast to ground beef (Laufer, Grass et al. 2015). While delicatessenstyle roast beef cooked in commercial processing establishments was the predominant type during the 1970s and early 1980s, regulations on cooking and processing virtually eliminated this problem by 1987 and ground beef emerged as an important vehicle in the 2000s (Laufer, Grass et al. 2015). In our survey, S. Typhimurium related outbreaks were mainly caused by fresh processed sausages and the main reason for food implication was undercooking or inappropriate hygienic practices during preparation. Interestingly, no reported Salmonella outbreak has occurred after 2010, where meat and meat products have been incriminated as a source of infection. Possibly this reflects improved meat hygiene, and not a publication bias.

\section{Food production systems}

In our survey, about $50 \%$ of the E. coli outbreaks, worldwide, were reported from the USA. It is reported, that regarding O157, including sporadic cases, $88 \%$ were traced to ground beef and $89 \%$ occurred in the US. High level of ground beef consumption at 
fast food restaurants and the availability of $E$. coli 0157 diagnostic methods were hypotheses explaining the large number of US outbreaks and cases (Hussein 2006). However, this trend was not seen from the Salmonella data, where only 2 out of 21 outbreaks caused by meats were reported from the USA. This is probably partly due to a significantly different prevalence in value chains, maybe consumption patterns, while medical, including diagnostic tools, and reporting systems are unlikely explanatory factors. However, different production systems that may relatively favour STEC but not Salmonella could also be of interest.

\section{Risk management}

Categorization schemes used for broad evaluation of risks across the entire food supply chain are likely to be quite different from those useful for targeted risk management (Batz, Hoffmann et al. 2012). Risk managers need to combine information both on outbreaks, incidence rates and pathogens' abilities to survive and grow to perform appropriate HACCP-analyses and make risk-based priorities. It is important that outbreak reports consider the relevant products' characterizations for pathogen growth and survival. A zero-risk level does not exist. An important question is therefore whether an outbreak occurred as a consequence of human errors like sublethal heat treatment or evitable cross-contamination, or if the outbreak is a result of an unlikely event. The Food Business Operators (FBO) are responsible for producing safe food. The trade-off between having food to eat and trust in safe consumption cannot be omitted. It is therefore our opinion that the reactions towards the FBOs should be conditional depending on the likely causation of outbreaks; it is a significantly different case when an outbreak may result from blameworthy errors or neglecting hygienic rules or principles, or if the outbreak is due to a systematic but accepted weakness of the regulations, product or the process.

\section{Potential biases}


We searched for the terms, "meat, fermented, outbreaks" as we were interested in particular, to illustrate different risks posed from raw cured fermented meats and other main product categories. The inclusion of the term 'fermented' may have generated a bias towards identifying more outbreaks generated by fermented meats. But we used different search resources to capture as many outbreaks as possible. We carried out a thorough search for published outbreaks in the literature. Outbreaks that occurred in the less developed countries and those that were reported in other languages than English, as well as many of those reported to national surveillance programs may have been missed. Outbreaks that may cause many severe clinical outcomes or cause many deaths, or where incentives are given to produce publications, may result in publication bias. As such, the representativeness of our data remains uncertain.

\section{Conclusions}

The recognition of dry fermented sausages as a potential threat to food safety has been recognized by several countries and measures has been taken to reduce the risks. Thus, the aims of the study were to review global outbreaks where red meat and meat products were incriminated as a source for outbreaks, with a focus on fermented meats. Our review seems to indicate that the number of reported outbreaks linked to meats may have declined over the last decades. Meat-related outbreaks are still dominated by Salmonella and VTEC. It is difficult to be certain on whether this trend is real, as there are many reporting potential biases in this area. We were not able to find enough reports to conclude on the potential risk for the public linked to cured, fermented sausages.

\section{Acknowledgements}

The authors acknowledge the financial contribution of the Research Council of Norway (project 244403/E50). 
322 Conflicts of interest: None.

\section{References}

Ahn CK, Russo AJ, Howell KR, Holt NJ, Sellenriek PL, Rothbaum RJ, Beck A M, Luebbering LJ, and Tarr PI. Deer Sausage: A Newly Identified Vehicle of Transmission of Escherichia coli O157:H7. J Pediatr 2009;155(4): 587-589.

Alexander ER, Boase J, Davis M, Kirchner L, Osaki C, Tanino T, Samadpour M, Tarr P, Goldoft M, Lankford S, Kobyashi J, Stehrgreen P, Bradley P, Hinton B, Tighe P, Pearson B, Flores GR, Abbott S, Bryant R, Werner SB and Vugia DJ. Eschericia-coli O157/H7 linked to commercially distributed dry-cured salami - Washington and California, 1994, VOL 44, PG 157-160, 1995). J Am Med Assoc 1995; 273(13): 985-986.

Ammon A, Petersen LR and Karch H. A large outbreak of hemolytic uremic syndrome caused by an unusual sorbitol-fermenting strain of Escherichia coli O157: H. J Infect Dis 1999; 179(5): 1274-1277.

Bacus J. Processing procedures to control Salmonella and E-coli in fermented sausage products. Food Aust 1997; 49(11): 543-547.

Batz MB, Doyle MP,Morris JG, Painter J, Singh R, Tauxe RV, Taylor MR, and Wong LF. Food Attribution Working Group. Attributing illness to food. Emerg Infect Diseases 2005; 11(7): 993-999.

Batz MB, Hoffmann S and Morris JG Jr. Ranking the Disease Burden of 14 Pathogens in Food Sources in the United States Using Attribution Data from Outbreak Investigations and Expert Elicitation. J Food Prot 2012; 75(7): 1278-1291.

Bell BP, Griffin PM, Lozano P, Christie DL, Kobayashi JM and Tarr PI. Predictors of hemolytic uremic syndrome in children during a large outbreak of Escherichia coli O157:H7 infections. Pediatrics 1997; 100(1): art. no.-e12.

Bennett SD, Walsh KA, and Gould LH. Foodborne Disease Outbreaks Caused by Bacillus cereus, Clostridium perfringens, and Staphylococcus aureus-United States, 1998-2008. Clin Infect Dis 2013; 57(3): 425-433. 
Brandt JR, Fouser LS, Watkins SL, Zelikovic I, Tarr PI, Nazarstewart V, and Avner ED. Escherichia-coli O157-H7-associated hemolytic-uremic syndrome syndrome after ingestion of contaminated hamburgers. J Pediatr 1994; 125(4): 519-526.

Bremer V, Leitmeyer K, Jensen E, Metzel U, Meczulat H, Weise E, Werber D, Tschaepe H, Kreienbrock L, Glaser S and Ammon A. Outbreak of Salmonella Goldcoast infections linked to consumption of fermented sausage, Germany 2001. Epidemiol Infect 2004;132(5): 881-887.

Brooks JT, Bergmire-Sweat D, Kennedy M, Hendricks K, Garcia M, Marengo L, Wells J, Ying M, Bibb W, Griffin PM, Hoekstra RM and Friedman CR. Outbreak of Shiga toxin - Producing Escherichia coli O111:H8 infections among attendees of a high school cheerleading camp. Clin Infect Dis 2004; 38(2): 190-198.

Brooks JT, Sowers EG, Wells JG, Greene KD, Griffin PM, Hoekstra RM and Strockbine NA. Non-O157 Shiga toxin-producing Escherichia coli infections in the United States, 1983-2002. J Infect Dis 2005;192(8): 1422-1429.

Bruun T, Sorensen G, Forshell LP, Jensen T, Nygard K, Kapperud G, Lindstedt BA, Berglund T, Wingstrand A, R. Petersen F, Muller L, Kjelso C, Ivarsson S, Hjertqvist M, Lofdahl S and Ethelberg S. An outbreak of Salmonella Typhimurium infections in Denmark, Norway and Sweden, 2008. Euro Surveill 2009); 14(10).

Callejon RM, Rodriguez-Naranjo MI, Ubeda C, R. Hornedo-Ortega, Garcia-Parrilla MC and Troncoso AM. Reported Foodborne Outbreaks Due to Fresh Produce in the United States and European Union: Trends and Causes. Foodborne Pathog Dis 2015; 12(1): 32-38.

CDC. Escherichia coli O157:H7 Outbreak Linked to Commercially Distributed Dry-Cured Salami -- Washington and California, 1994. MMWR Weekly1995; from http://www.cdc.gov/mmwr/PDF/wk/mm4409.pdf.

CDC. Botulism outbreak associated with eating fermented food-Alaska, MMWR,2001; 50(32): 680 - 682

CDC. Multistate outbreak of E. coli O157:H7 infections linked to Topp's brand ground beef patties (final update); 2007.

CDC. Multistate outbreak of E. coli O157:H7 infections linked to ground beef from Kroger/Nebraska Ltd. (final update); 2008.

CDC. Multistate outbreak of E. coli O157:H7 infections associated with beef from Fairbanks farms (final update); 2009.

CDC. Multistate outbreak of E. coli O157:H7 infections associated with beef from JBS Swift Beef Company (final update); 2009.

CDC. Multistate outbreak of E. coli O157:H7 infections associated with beef from National steak and poultry (final update). 2010. 
CDC. Multistate outbreak of E. coli O157:H7 infections associated with Lebanon Bologna (final update); 2011.

CDC. Multistate outbreak of Shiga toxin-producing Escherichia coli O157:H7 infections linked to ground Beed (Final update); 2014. Retrieved June 20, 2014.

CDC. Two multistate outbreaks of Shiga toxin--producing Escherichia coli infections linked to beef from a single slaughter facility United States, 2008. MMWR. 2010; 59(18): 557-560.

Conedera G, Mattiazzi E, Russo F, Chiesa E, Scorzato I, Grandesso S, Bessegato A, Fioravanti A and Caprioli A. A family outbreak of Escherichia coli 0157 haemorrhagic colitis caused by pork meat salami. Epidemiol Infect 2007; 135(2): 311-314.

Cowden JM, Ahmed S, Donaghy M and Riley A. Epidemiological investigation of the Central Scotland outbreak of Escherichia coli O157 infection, November to December 1996. Epidemiol Infect 2001; 126(3): 335-341.

Cowden JM, O'Mahony M, Bartlett CL, Rana B, Smyth B, Lynch D, Tillett H, Ward L, Roberts D, Gilbert RJ, et al. A national outbreak of Salmonella typhimurium DT 124 caused by contaminated salami sticks. Epidemiol Infect. 1989 Oct;103(2):219-25.

Currie A, Farber JM, Nadon C, Sharma D, Whitfield Y, Gaulin C, Galanis E, Bekal S, Flint J, Tschetter L, Pagotto F, Lee B, Jamieson F, Badiani T, MacDonald D, the National Outbreak Investigation Team, Ellis A, May-Hadford J, McCormick R, Savelli C, Middleton D, Allen V, Tremblay F-W, MacDougall L, Hoang L, Shyng S, Everett D, Chui L, Louie M, Bangura H, Levett PN, Wilkinson K, Wylie J, Reid J, Major B, Engel D, Douey D, Huszczynski G, Di Lecci J, Strazds J, Rousseau J, Ma K, Isaac L, and Sierpinska U. Multi-Province Listeriosis Outbreak Linked to Contaminated Deli Meat Consumed Primarily in Institutional Settings, Canada, 2008. Foodborne Pathog Dis 2015; 12(8): 645-652.

Dechet AM, Scallan E, Gensheimer K, Hoekstra R, Gunderman-King J, Lockett J, Wrigley D, Chege W, and Sobel J. Outbreak of multidrug-resistant Salmonella enterica serotype Typhimurium Definitive Type 104 infection linked to commercial ground beef, northeastern United States, 2003-2004. Clin Infect Dis 2006; 42(6): 747-752.

Dundas S, Todd WTA, Stewart AI, Murdoch PS, Chaudhuri AKR and Hutchinson SJ. The central Scotland Escherichia coli O157: H7 outbreak: Risk factors for the hemolytic uremic syndrome and death among hospitalized patients. Clin Infect Dis 2001; 33(7): 923-931.

EFSA. Tracing seeds, in particular fenugreek (Trigonella foenum-graecum) seeds, in relation to the Shiga toxin-producing E. coli (STEC) O104:H4 2011 Outbreaks in Germany and France. 2011; 8(7). 
EFSA. The European Union summary report on trends and sources of zoonoses, zoonotic agents and food-borne outbreaks in 2014. EFSA Journal 2015; 13(12):4329

Emberland KE, Nygård K, Heier BT, Aavitsland P, Lassen J, Stavnes TL, Gondrosen B. Outbreak of Salmonella Kedougou in Norway associated with salami, April-June 2006. Euro Surveill 2006 Jul 6;11(7):E060706.3.

Ethelberg S, Smith B, Torpdahl M, Lisby M, Boel J, Jensen T, Nielsen EM and Molbak K. Outbreak of Non-O157 Shiga ToxinProducing Escherichia coli Infection from Consumption of Beef Sausage. Clin Infect Dis 2009; 48(8): E78-E81.

Ethelberg S, Sorensen G, Kristensen B, Christensen K, Krusell L, Hempel-Jorgensen A, Perge A and Nielsen EM. Outbreak with multi-resistant Salmonella typhimurium DT104 linked to carpaccio, Denmark, 2005. Epidemiol Infect 2007; 135(6): 900-907.

EU Commission. Regulation (EC) No 2073/2005 of 15 November 2005 on microbiological criteria for foodstuffs. Off J EU; $2005: 26$.

EU Commission. Regulation (EC) No 853/2004 of 29 April 2004 laying down specific rules for food of animal origin. Off J EU 2004; L 226:93-127

Friesema IHM, Schimmer B, Ros JA, Ober HJ, Heck MEOC, Swaan CM, de Jager CM, Peran i Sala RM and van Pelt W. A Regional Salmonella enterica Serovar Typhimurium Outbreak Associated with Raw Beef Products, The Netherlands, 2010. Foodborne Pathog Dis 2012; 9(2): 102-107.

Gaulin C, Ramsay D, Catford A, and Bekal S. Escherichia coli O157:H7 Outbreak Associated with the Consumption of Beef and Veal Tartares in the Province of Quebec, Canada, in 2013. Foodborne Pathog Dis 2015; 12(7): 612-618.

Gilsdorf A1, Jansen A, Alpers K, Dieckmann H, van Treeck U, Hauri AM, Fell G, Littmann M, Rautenberg P, Prager R, Rabsch W, Roggentin P, Schroeter A, Miko A, Bartelt E, Braunig J, Ammon A. A nationwide outbreak of Salmonella Bovismorbificans PT24, Germany, December 2004-March 2005. Euro surveill 2005;10(3): E050324.050321-E050324.050321.

Gould LH, Walsh KA, Vieira AR, Herman K, Williams IT, Hall AJ and Cole D. Surveillance for Foodborne Disease Outbreaks United States, 1998-2008. MMWR Surveillance Summaries 2013; 62(2): 1-34.

Graves LM, Hunter SB, Ong AR, Schoonmaker-Bopp D, Hise K, Kornstein L, DeWitt WE, Hayes PS, Dunne E, Mead P and Swaminathan B. Microbiological aspects of the investigation that traced the 1998 outbreak of listeriosis in the United States to contaminated hot dogs and establishment of molecular subtyping-based surveillance for Listeria monocytogenes in the PulseNet network. J Clin Microbiol 2005; 43(5): 2350-2355. 
Greenland K, de Jager C, Heuvelink A, van der Zwaluw K, Heck M, Notermans D, van Pelt W and Friesema I. Nationwide outbreak of STEC 0157 infection in the Netherlands, December 2008-January 2009: continuous risk of consuming raw beef products. Euro Surveill 2009; 14(8).

Guerin P, Nygard K, Siitonen A, Vold L, Kuusi M, de Jong B, Rottingen J, Alvseike O, Olsson A, Lassen J, Andersson Y and Aavitsland P. Emerging Salmonella Enteritidis anaerogenic phage type 14b: Outbreak in Norwegian, Swedish and Finnish travellers returning from Greece. Euro Surveill 2006; 11(2).

Heiman KE, Mody RK, Johnson SD, Griffin PM and Gould LH. Escherichia coli O157 outbreaks in the United States, $2003-2012$. Emerg Infect Diseases 2015; $21(8): 1293$.

Heir E, Holck AL, Omer MK, Alvseike O, Hoy M, Mage I and Axelsson L. Reduction of verotoxigenic Escherichia coli by process and recipe optimisation in dry-fermented sausages. Int J Food Microbiol 2010; 141(3): 195-202.

Henning PH, Tham EBC, Martin AA, Beare TH and Jureidini KF. Haemolytic-uraemic syndrome outbreak caused by Escherichia coli O111: H-: clinical outcomes. Med J Aust 1998; 168(11): 552-555.

Hjertqvist M, I. Luzzi, S. Lofdahl, Olsson A, J. Radal and Andersson Y. Unusual phage pattern of Salmonella Typhimurium isolated from Swedish patients and Italian salami. Euro Surveill 2006; 11(2): E060209.060203-E060209.060203.

Holck A L, Axelsson L, Rode TM, Hoy M, Mage I, Alvseike O, L'Abee-Lund T M, Omer MK, Granum PE and Heir E.). Reduction of verotoxigenic Escherichia coli in production of fermented sausages. Meat Sci 2011;89 (3): 286-295.

Hussein H. Prevalence and pathogenicity of Shiga toxin-producing Escherichia coli in beef cattle and their products. J Anim Sci 2006; 85, E63-E72,

Jureidini KF, Henning PH, AlAbbad A, Keeley S, Paton JC and Paton AW. Outbreak of HUS associated with verotoxigenic E-coli and dry fermented sausage. Kidney Int 1997; 51(4): 1305-1305.

King LA, Loukiadis E, Mariani-Kurkdjian P, Haeghebaert S, Weill FX, Baliere C, Ganet S, Gouali M, Vaillant V, Pihier N, Callon H, Novo R, Gaillot O, Thevenot-Sergentet D, Bingen E, Chaud P, de Valk H. Foodborne transmission of sorbitol-fermenting

Escherichia coli O157: H7 via ground beef: an outbreak in northern France, 2011. Clin Microbiol Infect 2014; 20(12): O1136-O1144. 
Kivi M, Hofhuis A, Notermans DW, Wannet WJB, Heck MEOC, De Giessen AWV,. Van Duynhoven YTHP, Stenvers OFJ, Bosman A, and Van Pelt W. A beef-associated outbreak of Salmonella Typhimurium DT104 in The Netherlands with implications for national and international policy. Epidemiol Infect 2007; 135(6): 890-899.

Laine ES, Scheftel JM, Boxrud DJ, Vought KJ, Danila RN, Elfering KM, and Smith KE. Outbreak of Escherichia coli O157:H7 infections associated with nonintact blade-tenderized frozen steaks sold by door-to-door vendors. J Food Prot 2005; 68(6): 11981202.

Laufer AS, Grass J, Holt K, Whichard JM, Griffin PM and. Gould LH. Outbreaks of Salmonella infections attributed to beef-United States, 1973-2011. Epidemiol Infect 2015; 143(9): 2003-2013.

Llewellyn LJ, Evans MR and Palmer SR. Use of sequential case-control studies to investigate a community salmonella outbreak in Wales. J Epidemiol Community Health 1998; 52(4): 272-276.

Luzzi I, Galetta P, Massari M, Rizzo C, Dionisi AM, Filetici E, Cawthorne A, Tozzi A, Argentieri M, Bilei S, Busani L, Gnesivo C, Pendenza A, Piccoli A, Napoli P, Loffredo L, Trinito MO, Santarelli E, Ciofi degli Atti ML. An Easter outbreak of Salmonella Typhimurium DT 104A associated with traditional pork salami in Italy. Euro surveill 2007; 12(4): E11-12.

Lynch M, Tauxe R and Hedberg C. The growing burden of foodborne outbreaks due to contaminated fresh produce: risks and opportunities. Epidemiol Infect 2009; 137(3): 307-315.

MacDonald DM, Fyfe M, Paccagnella A, Trinidad A, Louie K, Patrick D. Escherichia coli O157: H7 outbreak linked to salami, British Columbia, Canada, 1999. Epidemiol Infect 2004; 132(2): 283-289.

Maertens de Noordhout C, Devleesschauwer B, Angulo FJ, Verbeke G, Haagsma J, Kirk M, Havelaar A and Speybroeck N. The global burden of listeriosis: a systematic review and meta-analysis. Lancet 2014; 14(11): 1073-1082.

Maguire HCF, Codd AA, Mackay VE, Rowe B and Mitchell E. A large outbreak of Human Salmonellosis traced to a local pig farm Epidemiol Infect 1993; 110(2): 239-246.

McCartney G1, Cowden J, Murray S and Ahmed S. The use of a new virtual cohort study design to investigate an outbreak of E. coli O157 linked to a supermarket delicatessen. Epidemiol Infect 2010; 138(10): 1439-1442.

Moore, J. E. Gastrointestinal outbreaks associated with fermented meats. Meat Sci 2004; 67(4): 565-568. 
Newell DG, Koopmans M, Verhoef L, Duizer E, Aidara-Kane A, Sprong H, Opsteegh M, Langelaar M, Threfall J, Scheutz F, van der Giessen J, Kruse H. Food-borne diseases - The challenges of 20 years ago still persist while new ones continue to emerge. Int J Food Microbiol 2010;139: S3-S15.

Nicolay N, Thornton L, Cotter S, Garvey P, Bannon O, McKeown P, Cormican M, Fisher I, Little C, Boxall N, De Pinna E, Peters TM, Cowden J, Salmon R, Mason B, Irvine N, Rooney P, O'Flanagan D. Salmonella enterica serovar Agona European outbreak associated with a food company. Epidemiol Infect 2011; 139(8): 1272-1280.

Nygard K, Lindstedt BA, Wahl W, Jensvoll L, Kjelso C, Molbak K, Torpdahl M and Kapperud G. Outbreak of Salmonella Typhimurium infection traced to imported cured sausage using MLVA-subtyping. Euro Surveill 2007; 12(3): E070315.070315E070315.070315.

O'Brien AD, Melton AR, Schmitt CK, McKee ML, Batts ML, Griffin DE. Profile of Escherichia-coli O157-H7 Pathogen Responsible for Hamburger-Borne Outbreak of Hemorrhagic Colitis and Hemolytic-Uremic Syndrome in Washington. J Clin Microbiol 1993; 31(10): 2799-2801.

O'Brien SJ, Gillespie IA, Sivanesan MA, Elson R, Hughes C, Adak GK. Publication bias in foodborne outbreaks of infectious intestinal disease and its implications for evidence-based food policy. England and Wales 1992-2003. Epidemiol Infect 2006; 134(4): 667-674.

Painter JA, Hoekstra RM, Ayers T, Tauxe RV, Braden CR, Angulo FJ, Griffin, PM. Attribution of Foodborne Illnesses, Hospitalizations, and Deaths to Food Commodities by using Outbreak Data, United States, 1998-2008. Emerg Infect Diseases 2013; 19(3): 407-415.

Paton AW, Ratcliff RM, Doyle RM, Seymour-Murray J, Davos D, Lanser JA and Paton JC. Molecular microbiological investigation of an outbreak of hemolytic-uremic syndrome caused by dry fermented sausage contaminated with Shiga-like toxin-producing Escherichia coli. J. Clin. Microbiol 1996; 34(7): 1622-1627.

Pires SM, Evers EG, van Pelt W, Ayers T, Scallan E, Angulo FJ, Havelaar A, Hald T Med-Vet-Net Workpackage. Attributing the Human Disease Burden of Foodborne Infections to Specific Sources. Foodborne Pathog Dis 2009; 6(4): 417-424.

Riley LW, Remis RS, Helgerson SD, McGee HB, Wells JG, Scotland BR, Hebert RJ, Olcott ES, Johnson LM, Hargrett NT, Blake PA, Cohen ML. Hemorrhagic colitis associated with a rare Escherichia coli serotype. N Engl J Med 1983; 308(12): 681-685. 
Riordan, DC, Duffy G, Sheridan J, Eblen BS, Whiting RC, Blair IS, McDowell, DA. Survival of Escherichia coli O157:H7 during the manufacture of pepperoni. J Food Prot 1998; 61: 146-151.

Rodrigue DC, Mast EE, Greene KD, Davis JP, Hutchinson MA, Wells JG, Barrett TJ, Griffin PM. A University Outbreak of Escherichia-coli O157/H7 Infections Associated with Roast Beef and Unusually Benign Clinical Course. J Infect Dis 1995; 172(4): $1122-1125$

Rossier P, Urfer E, Burnens A, Bille J, Francioli P, Méan F, Zwahlen A. Clinical features and analysis of the duration of colonisation during an outbreak of Salmonella braenderup gastroenteritis. Schweiz Med Wochenschr 2000; 130(34): 1185-1191.

Salmon RL, Farrell ID, Hutchison JG, Coleman DJ, Gross RJ, Fry NK, Rowe B, Palmer SR. A christening party outbreak of haemorrhagic colitis and haemolytic uraemic syndrome associated with Escherichia coli O 157.H7. Epidemiol Infect 1989; 103(2): 249-254.

Sartz L, De Jong B, Hjertqvist M, Plym-Forshell L, Alsterlund R, Löfdahl S, Osterman B, Ståhl A, Eriksson E, Hansson HB, Karpman D. An outbreak of Escherichia coli O157:H7 infection in southern Sweden associated with consumption of fermented sausage; aspects of sausage production that increase the risk of contamination. Epidemiol Infect 2008; 136(3): 370-380.

Sauer, C. J., J. Majkowski, S. Green and R. Eckel. Foodborne illness outbreak associated with a semi-dry fermented sausage product. J Food Prot 1997; 60(12): 1612-1617.

Scavia G, Ciaravino G, Luzzi I, Lenglet A, Ricci A, Barco L, Pavan A, Zaffanella F, Dionisi AM. A multistate epidemic outbreak of Salmonella Goldcoast infection in humans, June 2009 to March 2010: the investigation in Italy. Euro Surveill 2013 Mar $14 ; 18(11): 20424$

Schimmer B, Nygard K, Eriksen HM, Lassen J, Lindstedt BA, Brandal LT, Kapperud G and Aavitsland P. Outbreak of haemolytic uraemic syndrome in Norway caused by stx2-positive Escherichia coli 0103:H25 traced to cured mutton sausages. BMC Infect Dis 2008; 8: 41.

Soborg B, Lassen SG, Müller L, Jensen T, Ethelberg S, Mølbak K, Scheutz F. A verocytotoxin-producing E. coli outbreak with a surprisingly high risk of haemolytic uraemic syndrome, Denmark, September-October 2012. Euro Surveill 2013; 18(2): 8-10.

Stenfors Arnesen LP, Fagerlund A, Granum PE. From soil to gut: Bacillus cereus and its food poisoning toxins. FEMS Microbiol Rev. 2008 Jul;32(4):579-606 
Stewart G. Staphyococcus aureus. Foodborne pathogens: microbiology and molecular biology. P. Fratamico, Buhnia A. Smith. Norfolk, UK, Caister Academic Press: 273 - 284, 2005.

Stirling A, G. McCartney, Ahmed S and J. Cowden. An outbreak of Escherichia coli 0157 phage type 2 infection in Paisley, Scotland. Euro Surveill 2007; 12(8): E070823.070821-E070823.070821.

Synnott M, Morse DL, Maguire H, Majid F, Plummer M, Leicester M, Threlfall EJ, Cowden J. An Outbreak of SalmonellaMilkawasima Associated with Doner Kebabs Epidemiol Infect 1993; 111(3): 473-481.

Taplin J. Salmonella newport outbreak - Victoria. Commun Dis Intell 1982; 1: 3 - 6.

Tauxe RV. Emerging foodborne diseases: An evolving public health challenge. Emerg Infect Diseases 1997; 3(4): $425-434$.

Tilden J Jr, Young W, McNamara AM, Custer C, Boesel B, Lambert-Fair MA, Majkowski J, Vugia D, Werner SB, Hollingsworth J, Morris JG Jr. A new route of transmission for Escherichia coli: Infection from dry fermented salami. Am. J. Public Health 1996; 86(8): 1142-1145.

Tseng CK, Tsai CH, Tseng CH, Tseng YC, Lee FY, Huang WS. An outbreak of foodborne botulism in Taiwan. Int J Hyg Environ 2009; 212(1): 82-86.

van Netten P, Leenaerts J, Heikant GM, Mossel DA. A small outbreak of salmonellosis caused by Bologna sausage. Tijdschr Diergeneeskd 1986; 111(24): 1271-1275.

Vogt RL and Dippold L. Escherichia coli O157:H7 outbreak associated with consumption of ground beef, June-July 2002. Public Health Reports 2005; 120(2): 174-178.

Watahiki M, Isobe J, Kimata K, Shima T, Kanatani J, Shimizu M, Nagata A, Kawakami K, Yamada M, Izumiya H, lyoda S, MoritaIshihara T, Mitobe J, Terajima J, Ohnishi M, Sata T. Characterization of Enterohemorrhagic Escherichia coli O111 and O157 Strains Isolated from Outbreak Patients in Japan. J. Clin. Microbiol 52 2014; (8): 2757-2763.

Williams RC, Isaacs S, Decou ML, Richardson EA, Buffett MC, Slinger RW, Brodsky MH, Ciebin BW, Ellis A, Hockin J. Illness outbreak associated with Escherichia coli O157:H7 in Genoa salami. CMAJ 2000; 162(10): 1409-1413. 
Willshaw GA, Thirlwell J, Jones AP, Parry S, Salmon RL and Hickey M. Vero Cytotoxin-Producing Eschericia-coli O157 in Beef Burgers Linked to An Outbreak of Diarrhoea, Hemorrhagic Colitis and Hemolytic-Uremic Syndrome in Britain. Lett Appl Microbiol 1994; 19(5): 304-307.

Figure 1. The distribution of E. coli serovars identified in the reported outbreaks as related to the meat categories implicated Figure 2. The size of the reported E. coli and Salmonella outbreaks as related to the total reported number of cases per outbreakyear

Figure 3. Time-line trend graph for the reported E. coli and Salmonella outbreaks that shows number of outbreaks per year

Figure 4. The distribution of Salmonella serovars identified in the reported outbreaks as related to the meat categories implicated 


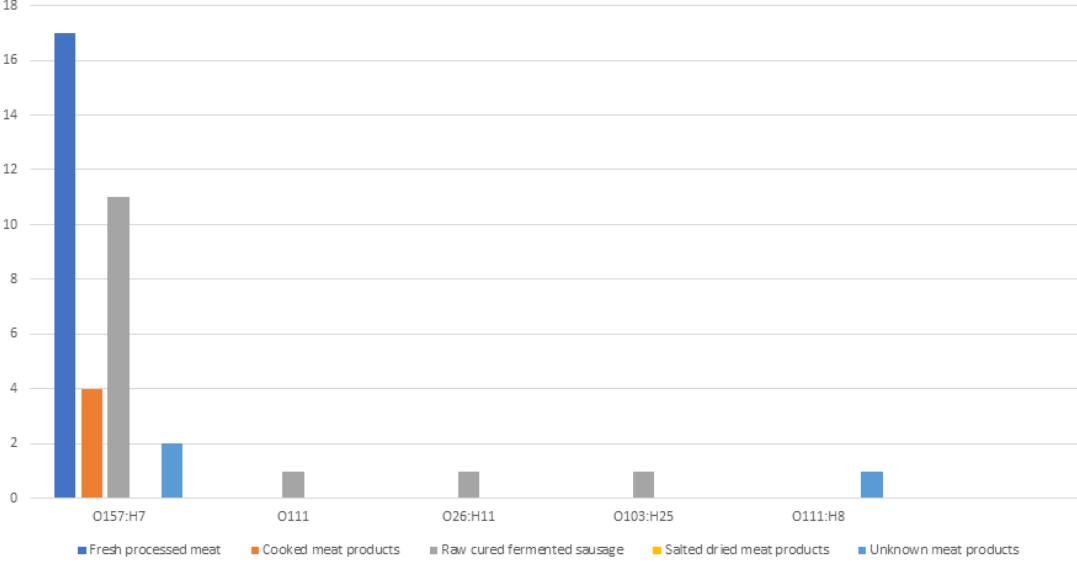




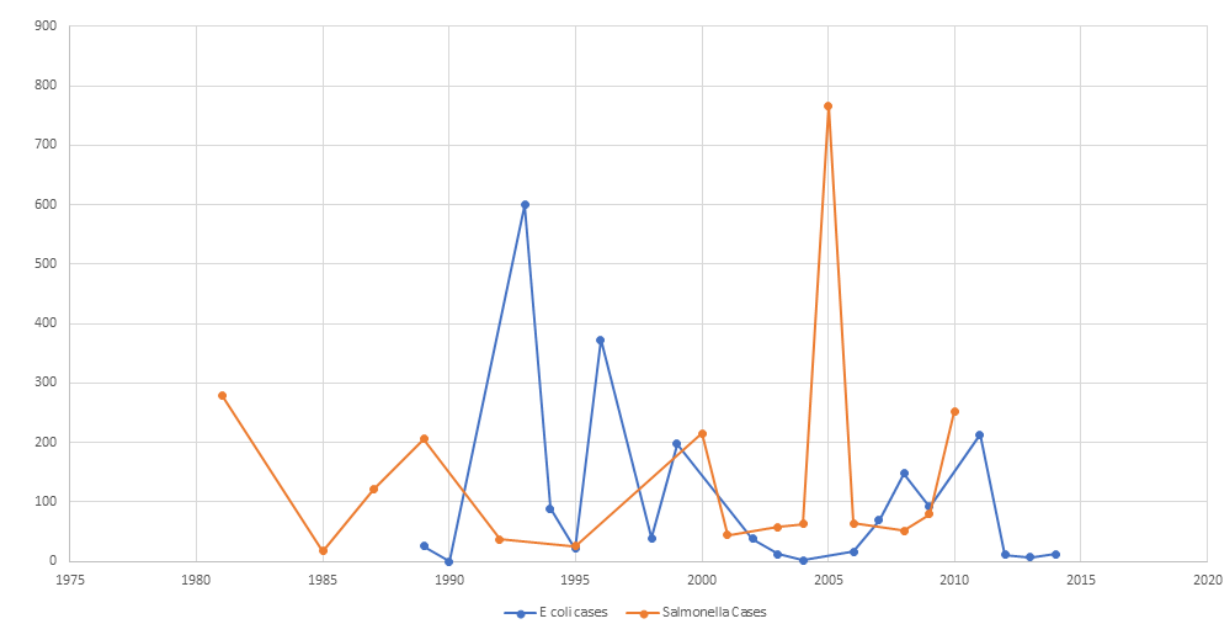




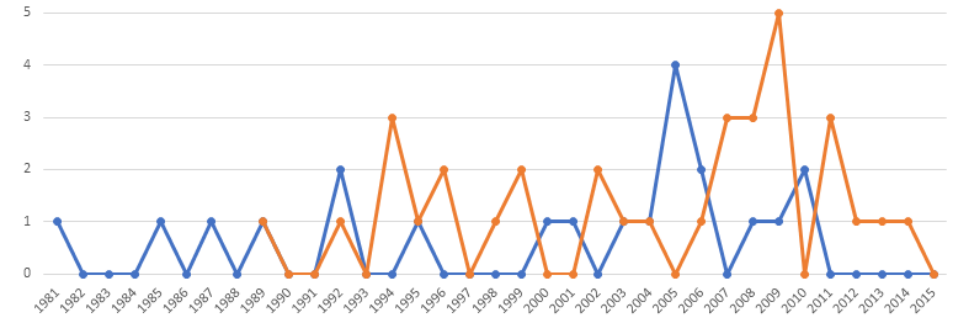

$\rightarrow$ Salmonella outreats $\rightarrow$ E. coli Oubbreats 


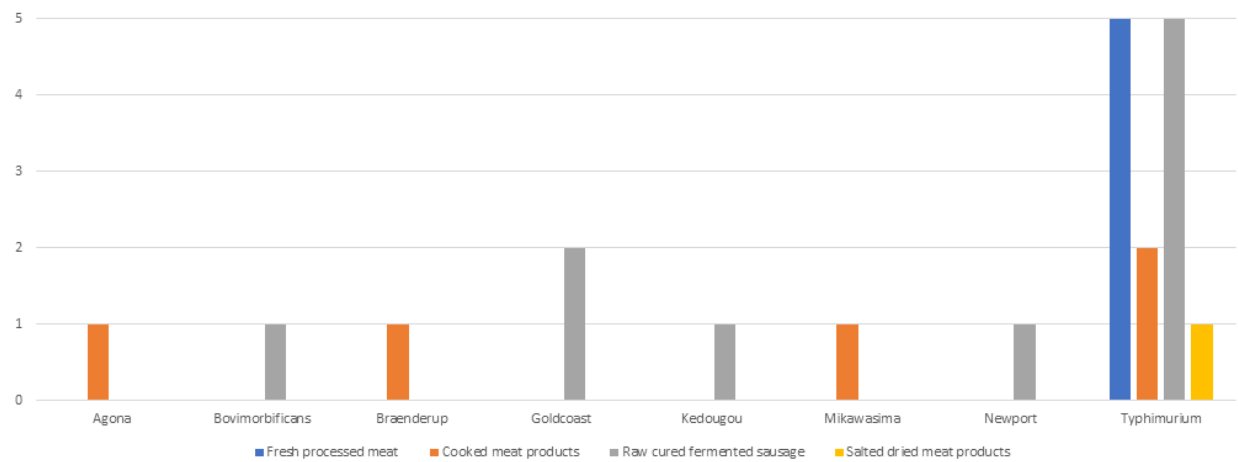

Table 1. Outbreaks caused by Shiga toxin-producing E. coli

\begin{tabular}{|c|c|c|c|c|c|c|c|c|c|c|c|c|}
\hline $\begin{array}{l}\text { Outbreak } \\
\text { Year }\end{array}$ & Biovar & $\begin{array}{l}\text { Food } \\
\text { incriminated }\end{array}$ & $\begin{array}{l}\text { Food } \\
\text { category }\end{array}$ & Main reason & $\begin{array}{l}\text { No. of } \\
\text { cases }\end{array}$ & $\begin{array}{l}\text { Age } \\
\text { median }\end{array}$ & $\begin{array}{l}\text { Laboratory- } \\
\text { confirmed }\end{array}$ & $\begin{array}{l}\text { Cases } \\
\text { with } \\
\text { HUS }\end{array}$ & $\begin{array}{l}\text { Hospital- } \\
\text { ization }\end{array}$ & Death & Location & Reference \\
\hline 1989 & O157H7 & $\begin{array}{l}\text { Turkey roll/ } \\
\text { tinned } \\
\text { frankfurter } \\
\text { sausages/ } \\
\text { pork pie }\end{array}$ & $\begin{array}{c}\text { Cooked } \\
\text { meat } \\
\text { products }\end{array}$ & $\begin{array}{c}\text { cross- } \\
\text { contamination }\end{array}$ & 26 & 25 & 13 & 1 & 6 & 0 & England & $\begin{array}{c}\text { (Salmon, Farrell } \\
\text { et al. 1989) }\end{array}$ \\
\hline
\end{tabular}




\begin{tabular}{|c|c|c|c|c|c|c|c|c|c|c|c|c|}
\hline $\begin{array}{l}1992 / \\
1993\end{array}$ & O157H7 & Hamburgers & $\begin{array}{c}\text { Fresh } \\
\text { processed } \\
\text { meat }\end{array}$ & undercooked & 600 & 6 & 501 & 39 & 39 & 3 & USA & $\begin{array}{l}\text { (Obrien, Melton } \\
\text { et al. 1993, } \\
\text { Brandt, Fouser } \\
\text { et al. 1994, Bell, } \\
\text { Griffin et al. } \\
\text { 1997) }\end{array}$ \\
\hline 1994 & $\mathrm{O} 157 \mathrm{H} 7$ & Hamburgers & $\begin{array}{c}\text { Fresh } \\
\text { processed } \\
\text { meat }\end{array}$ & undercooked & 8 & NA & 7 & NA & NA & & UK & $\begin{array}{c}\text { (Willshaw, } \\
\text { Thirlwell et al. } \\
\text { 1994) }\end{array}$ \\
\hline 1994 & $\mathrm{O} 157 \mathrm{H} 7$ & $\begin{array}{c}\text { Roast } \\
\text { beef/waldrof } \\
\text { salat }\end{array}$ & $\begin{array}{l}\text { Cooked } \\
\text { meat } \\
\text { products }\end{array}$ & undercooked & 61 & 28 & 35 & 0 & 0 & 0 & USA & $\begin{array}{c}\text { (Rodrigue, Mast } \\
\text { et al. 1995) }\end{array}$ \\
\hline 1994 & O157H7 & $\begin{array}{l}\text { Dry-Cured } \\
\text { Salami }\end{array}$ & $\begin{array}{l}\text { Raw cured } \\
\text { fermented } \\
\text { sausage }\end{array}$ & $\begin{array}{l}\text { No errors in } \\
\text { food handling } \\
\text { observed }\end{array}$ & 20 & 6 & 20 & 1 & 3 & & USA & $\begin{array}{c}\text { (Alexander, } \\
\text { Boase et al. } \\
\text { 1995, CDC } \\
\text { 1995, Tilden, } \\
\text { Young et al. } \\
\text { 1996) }\end{array}$ \\
\hline 1995 & 0111 & $\begin{array}{l}\text { Semi-Dry } \\
\text { Fermented } \\
\text { Sausage } \\
\text { (mettwûrst) }\end{array}$ & $\begin{array}{l}\text { Raw cured } \\
\text { fermented } \\
\text { sausage }\end{array}$ & $\begin{array}{c}\text { short } \\
\text { maturation? }\end{array}$ & 21 & NA & 20 & 21 & 20 & 1 & Australia & $\begin{array}{l}\text { (Paton, Ratcliff } \\
\text { et al. 1996, } \\
\text { Jureidini, } \\
\text { Henning et al. } \\
\text { 1997, Henning, } \\
\text { Tham et al. } \\
\text { 1998) }\end{array}$ \\
\hline 1996 & O157H7 & $\begin{array}{c}\text { (Mortadella) } \\
\text { Teewürst }\end{array}$ & $\begin{array}{l}\text { Cooked } \\
\text { meat } \\
\text { products, } \\
\text { Raw cured } \\
\text { fermented } \\
\text { sausage }\end{array}$ & Raw meat? & 28 & $\mathrm{NA}$ & 12 & 28 & 12 & 3 & Germany & $\begin{array}{c}\text { (Ammon, } \\
\text { Petersen et al. } \\
\text { 1999) }\end{array}$ \\
\hline 1996 & $\mathrm{O} 157 \mathrm{H} 7$ & $\begin{array}{l}\text { contaminated } \\
\text { cooked meats }\end{array}$ & $\begin{array}{l}\text { Cooked } \\
\text { meat } \\
\text { products }\end{array}$ & $\begin{array}{c}\text { cross- } \\
\text { contamination }\end{array}$ & 345 & 63 & 279 & 34 & 120 & 16 & Scotland & $\begin{array}{l}\text { (Cowden, } \\
\text { Ahmed et al. } \\
\text { 2001, Dundas, } \\
\text { Todd et al. } \\
\text { 2001) }\end{array}$ \\
\hline 1998 & O157H7 & Genoa salami & $\begin{array}{c}\text { Raw cured } \\
\text { fermented } \\
\text { sausage }\end{array}$ & $\begin{array}{c}\text { short } \\
\text { maturation? }\end{array}$ & 39 & 16 & 36 & 2 & 14 & & Canada & $\begin{array}{l}\text { (Williams, } \\
\text { Isaacs et al. } \\
2000)\end{array}$ \\
\hline 1999 & $\mathrm{O} 111 \mathrm{H} 8$ & Various & NA & NA & 55 & 16 & 2 & 2 & 2 & & USA & $\begin{array}{c}\text { (Brooks, } \\
\text { Bergmire-Sweat } \\
\text { et al. 2004) }\end{array}$ \\
\hline
\end{tabular}




\begin{tabular}{|c|c|c|c|c|c|c|c|c|c|c|c|c|}
\hline 1999 & $\mathrm{O} 157 \mathrm{H} 7$ & Salami & $\begin{array}{l}\text { Raw cured } \\
\text { fermented } \\
\text { sausage }\end{array}$ & NA & 143 & 12 & 143 & 6 & 42 & 0 & Canada & $\begin{array}{c}\text { (MacDonald, } \\
\text { Fyfe et al. 2004) }\end{array}$ \\
\hline 2002 & $\mathrm{O} 157 \mathrm{H} 7$ & $\begin{array}{l}\text { Fermented } \\
\text { sausage }\end{array}$ & $\begin{array}{l}\text { Raw cured } \\
\text { fermented } \\
\text { sausage }\end{array}$ & NA & 30 & 19 & 29 & 9 & 13 & 0 & Sweden & $\begin{array}{l}\text { (Sartz, De Jong } \\
\text { et al. 2008) }\end{array}$ \\
\hline 2002 & $\mathrm{O} 157 \mathrm{H} 7$ & Minced meat & $\begin{array}{c}\text { Fresh } \\
\text { processed } \\
\text { meat }\end{array}$ & Undercooked & 8 & 14 & 7 & 3 & 3 & 0 & USA & $\begin{array}{c}\text { (Vogt and } \\
\text { Dippold 2005) }\end{array}$ \\
\hline 2003 & O157H7 & $\begin{array}{c}\text { Tenderized } \\
\text { marinated } \\
\text { steak }\end{array}$ & $\begin{array}{c}\text { Fresh } \\
\text { processed } \\
\text { meat }\end{array}$ & undercooked & 12 & NA & 10 & 1 & 0 & 0 & USA & $\begin{array}{l}\text { (Laine, Scheftel } \\
\text { et al. 2005) }\end{array}$ \\
\hline 2004 & $\mathrm{O} 157 \mathrm{H} 7$ & $\begin{array}{l}\text { Dry-fermented } \\
\text { pork salami }\end{array}$ & $\begin{array}{l}\text { Raw cured } \\
\text { fermented } \\
\text { sausage }\end{array}$ & NA & 2 & 60 & 2 & 0 & 2 & 0 & Italy & $\begin{array}{c}\text { (Conedera, } \\
\text { Mattiazzi et al. } \\
2007)\end{array}$ \\
\hline 2006 & $\mathrm{O} 103 \mathrm{H} 25$ & $\begin{array}{l}\text { Dry cured } \\
\text { sausage }\end{array}$ & $\begin{array}{c}\text { Raw cured } \\
\text { fermented } \\
\text { sausage }\end{array}$ & NA & 16 & NA & 15 & 10 & 14 & 1 & Norway & $\begin{array}{c}\text { (Schimmer, } \\
\text { Nygard et al. } \\
2008)\end{array}$ \\
\hline 2007 & O157H7 & Beef cooked & $\begin{array}{l}\text { Cooked } \\
\text { meat } \\
\text { product }\end{array}$ & $\begin{array}{c}\text { cross- } \\
\text { contamination }\end{array}$ & 9 & 70 & 9 & NA & NA & 1 & Scotland & $\begin{array}{c}\text { (Stirling, } \\
\text { McCartney et al. } \\
2007, \\
\text { McCartney, } \\
\text { Cowden et al. } \\
2010)\end{array}$ \\
\hline 2007 & $\mathrm{O} 157 \mathrm{H} 7$ & $\begin{array}{l}\text { Frozen ground } \\
\text { patties }\end{array}$ & $\begin{array}{c}\text { Fresh } \\
\text { processed } \\
\text { meat }\end{array}$ & undercooked & 40 & NA & 40 & 2 & 25 & 0 & USA & (CDC 2007) \\
\hline 2007 & $\mathrm{O} 26 \mathrm{H} 11$ & $\begin{array}{c}\text { Organic } \\
\text { fermented beef } \\
\text { sausage }\end{array}$ & $\begin{array}{c}\text { Raw cured } \\
\text { fermented } \\
\text { sausage }\end{array}$ & NA & 20 & 2 & 20 & 0 & 0 & 0 & Denmark & $\begin{array}{l}\text { (Ethelberg, } \\
\text { Smith et al. } \\
\text { 2009) }\end{array}$ \\
\hline 2008 & O157H7 & Ground beef & $\begin{array}{c}\text { Fresh } \\
\text { processed } \\
\text { meat }\end{array}$ & NA & 64 & 21 & 64 & 2 & 38 & 0 & USA & (CDC 2010) \\
\hline 2008 & $\mathrm{O} 157 \mathrm{H} 7$ & Ground beef & $\begin{array}{c}\text { Fresh } \\
\text { processed } \\
\text { meat }\end{array}$ & NA & 35 & 18,5 & 35 & 1 & 22 & 0 & USA & $($ (CDC 2010) \\
\hline 2008 & $\mathrm{O} 157 \mathrm{H} 7$ & Ground beef & $\begin{array}{c}\text { Fresh } \\
\text { processed } \\
\text { meat }\end{array}$ & undercooked & 49 & NA & 49 & $\mathrm{NA}$ & 27 & & USA & $($ (CDC 2008) \\
\hline 2009 & O157H7 & $\begin{array}{c}\text { Fermented } \\
\text { deer sausage }\end{array}$ & $\begin{array}{c}\text { Raw cured } \\
\text { fermented } \\
\text { sausage }\end{array}$ & $\begin{array}{l}\text { non-compliant } \\
\text { small scale } \\
\text { production }\end{array}$ & 5 & 6 & 5 & 2 & 5 & 0 & USA & $\begin{array}{l}\text { (Ahn, Russo et } \\
\text { al. 2009) }\end{array}$ \\
\hline
\end{tabular}




\begin{tabular}{|c|c|c|c|c|c|c|c|c|c|c|c|c|}
\hline 2009 & $\mathrm{O} 157 \mathrm{H} 7$ & Steak tartare & $\begin{array}{c}\text { Fresh } \\
\text { processed } \\
\text { meat }\end{array}$ & undercooked & 17 & 41 & 17 & 0 & 7 & 0 & Holland & $\begin{array}{c}\text { (Greenland, de } \\
\text { Jager et al. } \\
\text { 2009) }\end{array}$ \\
\hline 2009 & $\mathrm{O} 157 \mathrm{H} 7$ & $\begin{array}{l}\text { Beef primals, } \\
\text { ground beef }\end{array}$ & $\begin{array}{c}\text { Fresh } \\
\text { processed } \\
\text { meat }\end{array}$ & undercooked & 23 & $\mathrm{NA}$ & 17 & 2 & 16 & 0 & USA & (CDC 2009) \\
\hline 2009 & O157H7 & Ground beef & $\begin{array}{c}\text { Fresh } \\
\text { processed } \\
\text { meat }\end{array}$ & NA & 26 & $\mathrm{NA}$ & 24 & 5 & 19 & 2 & USA & (CDC 2009) \\
\hline 2009 & O157H7 & $\begin{array}{c}\text { Beef } \\
\text { tenderized }\end{array}$ & $\begin{array}{c}\text { Fresh } \\
\text { processed } \\
\text { meat }\end{array}$ & NA & 21 & 34 & 21 & 1 & 9 & 0 & USA & (CDC 2010) \\
\hline 2011 & $\mathrm{O} 157 \mathrm{H} 7$ & $\begin{array}{c}\text { Lebanon } \\
\text { bologna beef } \\
\text { semi-dry } \\
\text { fermented }\end{array}$ & $\begin{array}{c}\text { Raw cured } \\
\text { fermented } \\
\text { sausage }\end{array}$ & NA & 14 & 13,5 & 14 & 0 & 3 & 0 & USA & (CDC 2011) \\
\hline 2011 & O157H7 & Beef raw & $\begin{array}{c}\text { Fresh } \\
\text { processed } \\
\text { meat }\end{array}$ & undercooked & 181 & NA & 55 & 34 & NA & 5 & Japan & $\begin{array}{c}\text { (Watahiki, Isobe } \\
\text { et al. 2014) }\end{array}$ \\
\hline 2011 & $\mathrm{O} 157 \mathrm{H} 7$ & $\begin{array}{c}\text { frozen ground } \\
\text { beef }\end{array}$ & $\begin{array}{c}\text { Fresh } \\
\text { processed } \\
\text { meat }\end{array}$ & NA & 18 & $\mathrm{NA}$ & 12 & 18 & 6 & 0 & France & $\begin{array}{l}\text { (King, Loukiadis } \\
\text { et al. 2014) }\end{array}$ \\
\hline 2012 & $\mathrm{O} 157 \mathrm{H} 7$ & Ground beef & $\begin{array}{c}\text { Fresh } \\
\text { processed } \\
\text { meat }\end{array}$ & undercooked & 11 & 14 & 11 & 8 & $\mathrm{NA}$ & NA & Denmark & $\begin{array}{l}\text { (Soborg, Lassen } \\
\text { et al. 2013) }\end{array}$ \\
\hline 2013 & O157H7 & Beef tartare & $\begin{array}{c}\text { Fresh } \\
\text { processed } \\
\text { meat }\end{array}$ & undercooked & 7 & NA & 7 & 1 & 2 & 0 & Canada & $\begin{array}{c}\text { (Gaulin, } \\
\text { Ramsay et al. } \\
2015)\end{array}$ \\
\hline 2014 & $\mathrm{O} 157 \mathrm{H7}$ & Ground beef & $\begin{array}{c}\text { Fresh } \\
\text { processed } \\
\text { meat }\end{array}$ & undercooked & 12 & 25 & 12 & 0 & 7 & 0 & USA & (CDC 2014) \\
\hline
\end{tabular}

${ }^{*}$ Not available

Table 2: Reported outbreaks caused by Salmonella spp. 


\begin{tabular}{|c|c|c|c|c|c|c|c|c|c|c|c|}
\hline $\begin{array}{l}\text { Outbrea } \\
\text { k Year }\end{array}$ & Biovar & $\begin{array}{l}\text { Food } \\
\text { incriminated }\end{array}$ & $\begin{array}{l}\text { Food } \\
\text { Categor } \\
y\end{array}$ & Main reason & $\begin{array}{c}\text { No. } \\
\text { of } \\
\text { case } \\
s\end{array}$ & $\begin{array}{c}\text { Age } \\
\text { media } \\
n\end{array}$ & $\begin{array}{c}\text { Laborator } \\
y- \\
\text { confirmed }\end{array}$ & $\begin{array}{c}\text { Hospitalizatio } \\
n\end{array}$ & $\begin{array}{c}\text { Deat } \\
h\end{array}$ & Location & Reference \\
\hline 1981 & Newport & Salami & $\begin{array}{l}\text { Raw } \\
\text { cured } \\
\text { fermente } \\
\text { d } \\
\text { sausage }\end{array}$ & $\mathrm{NA}^{*}$ & 279 & NA & 279 & 2 & NA & Australia & $\begin{array}{l}\text { (Taplin } \\
\text { 1982) }\end{array}$ \\
\hline 1985 & Typhimurium & $\begin{array}{l}\text { Bologna } \\
\text { fermented } \\
\text { sausage }\end{array}$ & $\begin{array}{l}\text { Raw } \\
\text { cured } \\
\text { fermente } \\
\text { d } \\
\text { sausage }\end{array}$ & NA & 17 & NA & 17 & 0 & 0 & Holland & $\begin{array}{l}\text { van } \\
\text { Netten, } \\
\text { Leenaerts } \\
\text { et al. } \\
1986) \\
\end{array}$ \\
\hline 1987 & Typhimurium & $\begin{array}{l}\text { Salami sticks } \\
\text { Germany }\end{array}$ & $\begin{array}{l}\text { Raw } \\
\text { cured } \\
\text { fermente } \\
\text { d } \\
\text { sausage }\end{array}$ & short maturation? & 121 & 6 & 101 & 19 & NA & England & $\begin{array}{l}\text { (Cowden, } \\
\text { O'Mahony } \\
\text { et al. } \\
1989 \text { ) }\end{array}$ \\
\hline 1989 & Typhimurium & cold roasted pork & $\begin{array}{l}\text { Cooked } \\
\text { meat } \\
\text { products }\end{array}$ & $\begin{array}{l}\text { Inadequate } \\
\text { heating }\end{array}$ & 206 & $\mathrm{NA}$ & 31 & 19 & 0 & England & $\begin{array}{l}\text { (Maguire, } \\
\text { Codd et al. } \\
\text { 1993) }\end{array}$ \\
\hline 1992 & Mikawasima & Döner kebab & $\begin{array}{l}\text { Cooked } \\
\text { meat } \\
\text { products }\end{array}$ & $\begin{array}{l}\text { Cooking \& } \\
\text { handling } \\
\text { faults/contaminati } \\
\text { on }\end{array}$ & 9 & 25 & 9 & 0 & 0 & England & $\begin{array}{l}\text { (Synnott, } \\
\text { Morse et } \\
\text { al. 1993) }\end{array}$ \\
\hline 1992 & Typhimurium & $\begin{array}{l}\text { Cooked ham re- } \\
\text { contaminated }\end{array}$ & $\begin{array}{l}\text { Cooked } \\
\text { meat } \\
\text { products }\end{array}$ & Faulty cooking & 28 & NA & 28 & 2 & 1 & Wales, UK & $\begin{array}{l}\text { (Llewellyn, } \\
\text { Evans et } \\
\text { al. 1998) }\end{array}$ \\
\hline 1995 & Typhimurium & $\begin{array}{l}\text { Lebanon bologna } \\
\text { Semidry } \\
\text { fermented } \\
\text { sausage }\end{array}$ & $\begin{array}{l}\text { Raw } \\
\text { cured } \\
\text { fermente } \\
\text { d } \\
\text { sausage }\end{array}$ & bad procedures & 26 & NA & 26 & NA & NA & USA & $\begin{array}{l}\text { (Sauer, } \\
\text { Majkowski } \\
\text { et al. } \\
\text { 1997) }\end{array}$ \\
\hline 2000 & Braenderup & Meat pies & $\begin{array}{l}\text { Cooked } \\
\text { meat } \\
\text { products }\end{array}$ & bad procedures & 215 & NA & 215 & $\mathrm{NA}$ & $\mathrm{NA}$ & Switzerland & $\begin{array}{l}\text { (Rossier, } \\
\text { Urfer et al. } \\
2000 \text { ) }\end{array}$ \\
\hline 2001 & Goldcoast & $\begin{array}{l}\text { Fermented } \\
\text { sausage }\end{array}$ & $\begin{array}{l}\text { Raw } \\
\text { cured } \\
\text { fermente } \\
\text { d } \\
\text { sausage }\end{array}$ & NA & 44 & 54 & 44 & NA & NA & Germany & $\begin{array}{l}\text { (Bremer, } \\
\text { Leitmeyer } \\
\text { et al. } \\
2004 \text { ) }\end{array}$ \\
\hline
\end{tabular}




\begin{tabular}{|c|c|c|c|c|c|c|c|c|c|c|c|}
\hline $\begin{array}{l}2003- \\
2004\end{array}$ & Typhimurium & Ground beef & $\begin{array}{l}\text { Fresh } \\
\text { processe } \\
\mathrm{d} \text { meat }\end{array}$ & NA & 58 & 49 & 30 & 11 & 0 & USA & $\begin{array}{l}\text { (Dechet, } \\
\text { Scallan et } \\
\text { al. 2006) }\end{array}$ \\
\hline 2004 & Typhimurium & $\begin{array}{l}\text { Salami corallina } \\
\text { Fermented pork } \\
\text { salami }\end{array}$ & $\begin{array}{l}\text { Raw } \\
\text { cured } \\
\text { fermente } \\
\text { d } \\
\text { sausage }\end{array}$ & undercooked & 63 & 7,5 & 63 & NA & $\mathrm{NA}$ & Italy & $\begin{array}{l}\text { (Luzzi, } \\
\text { Galetta et } \\
\text { al. 2007) }\end{array}$ \\
\hline 2005 & $\begin{array}{l}\text { Bovimorbifica } \\
\text { ns }\end{array}$ & $\begin{array}{l}\text { Pork raw minced/ } \\
\text { fermented } \\
\text { sausage } \\
\text { (Zwiebelmettwur } \\
\text { st) }\end{array}$ & $\begin{array}{l}\text { Raw } \\
\text { cured } \\
\text { fermente } \\
\text { d } \\
\text { sausage }\end{array}$ & NA & 525 & $\mathrm{NA}$ & 525 & NA & 1 & Germany & $\begin{array}{l}\text { (Gilsdorf, } \\
\text { Jansen et } \\
\text { al. 2005) }\end{array}$ \\
\hline 2005 & Typhimurium & Salami Italian & $\begin{array}{l}\text { Raw } \\
\text { cured } \\
\text { fermente } \\
\text { d } \\
\text { sausage }\end{array}$ & undercooked & 32 & NA & 15 & NA & NA & Sweden & $\begin{array}{l}\text { (Hjertqvist, } \\
\text { Luzzi et al. } \\
2006 \text { ) }\end{array}$ \\
\hline 2005 & Typhimurium & Capaccio Italian & $\begin{array}{l}\text { Fresh } \\
\text { processe } \\
d \text { meat }\end{array}$ & NA & 40 & $\mathrm{NA}$ & 32 & NA & 0 & Denmark & $\begin{array}{l}\text { (Ethelberg, } \\
\text { Sorensen } \\
\text { et al. } \\
2007 \text { ) }\end{array}$ \\
\hline 2005 & Typhimurium & $\begin{array}{l}\text { Beef Italian steak } \\
\text { tartare }\end{array}$ & $\begin{array}{l}\text { Fresh } \\
\text { processe } \\
d \text { meat }\end{array}$ & $\begin{array}{l}\text { raw meat } \\
\text { consumption }\end{array}$ & 169 & NA & 32 & $\mathrm{NA}$ & $\mathrm{NA}$ & Holland & $\begin{array}{l}\text { (Kivi, } \\
\text { Hofhuis et } \\
\text { al. 2007) }\end{array}$ \\
\hline 2006 & Kedougou & $\begin{array}{l}\text { Salami danish } \\
\text { style }\end{array}$ & $\begin{array}{l}\text { Raw } \\
\text { cured } \\
\text { fermente } \\
\text { d } \\
\text { sausage }\end{array}$ & NA & 54 & $\mathrm{NA}$ & 54 & NA & 1 & Norway & $\begin{array}{l}\text { Emberlan } \\
\text { d KE et al. } \\
2006\end{array}$ \\
\hline 2006 & Typhimurium & Spanish chorizo & $\begin{array}{l}\text { Salted } \\
\text { dried } \\
\text { meat } \\
\text { products }\end{array}$ & undercooked & 10 & $\mathrm{NA}$ & 10 & $\mathrm{NA}$ & $\mathrm{NA}$ & $\begin{array}{l}\text { Norway/Denmar } \\
\text { k/ }\end{array}$ & $\begin{array}{l}\text { (Nygard, } \\
\text { Lindstedt } \\
\text { et al. } \\
2007 \text { ) }\end{array}$ \\
\hline 2008 & Typhimurium & Fresh pork & $\begin{array}{l}\text { Fresh } \\
\text { processe } \\
d \text { meat }\end{array}$ & NA & 51 & 54 & 51 & NA & 4 & $\begin{array}{l}\text { Norway, } \\
\text { Denmark } \\
\text { Sweden }\end{array}$ & $\begin{array}{l}\text { (Bruun, } \\
\text { Sorensen } \\
\text { et al. } \\
2009 \text { ) }\end{array}$ \\
\hline 2009 & Goldcoast & $\begin{array}{l}\text { Salami } \\
\text { Mantovano }\end{array}$ & $\begin{array}{l}\text { Raw } \\
\text { cured } \\
\text { fermente } \\
\text { d } \\
\text { sausage }\end{array}$ & $\begin{array}{l}\text { raw meat } \\
\text { consuption }\end{array}$ & 79 & 50 & 79 & NA & $\mathrm{NA}$ & Italy & $\begin{array}{l}\text { Scavia et } \\
\text { al. } 2013\end{array}$ \\
\hline
\end{tabular}




\begin{tabular}{|c|c|c|c|c|c|c|c|c|c|c|c|}
\hline 2010 & Agona & Precooked meat & $\begin{array}{l}\text { Cooked } \\
\text { meat } \\
\text { products }\end{array}$ & undercooked & 163 & & 163 & NA & NA & Ireland & $\begin{array}{l}\text { (Nicolay, } \\
\text { Thornton } \\
\text { et al. } \\
2011 \text { ) }\end{array}$ \\
\hline 2010 & Typhimurium & $\begin{array}{l}\text { Ground } \\
\text { beef/ossenworst }\end{array}$ & $\begin{array}{l}\text { Fresh } \\
\text { processe } \\
d \text { meat }\end{array}$ & undercooked & 90 & 22 & $97 \%$ & $46 \%$ & NA & Holland & $\begin{array}{l}\text { (Friesema, } \\
\text { Schimmer } \\
\text { et al. } \\
2012 \text { ) }\end{array}$ \\
\hline
\end{tabular}

NA* Not available

Table 3: Meat product categories related to reported cases with Hemolytic Uremic Syndrome (HUS)

\begin{tabular}{|l|c|c|c|c|}
\hline Meat category & $\begin{array}{c}\text { Cases With } \\
\text { HUS }\end{array}$ & $\begin{array}{c}\text { Total cases within } \\
\text { category }\end{array}$ & $\begin{array}{c}\text { HUS within } \\
\text { category }\end{array}$ & $\begin{array}{c}\text { HUS of all cases } \\
(\mathrm{N}=1966)\end{array}$ \\
\hline Fresh processed meat & 117 & 1132 & $10.3 \%$ & 16.4 \\
\hline Raw cured fermented sausage & 51 & 310 & 13.4 & 2.6 \\
\hline Cooked meat products & 63 & 469 & 3.6 & 3.2 \\
\hline Unknown meat products & 2 & 55 & & 0.1 \\
\hline Salted dried meat products & NA $^{*}$ & NA & $\mathbf{1 1 . 8}$ & \\
\hline Sum ALL & $\mathbf{2 3 3}$ & $\mathbf{1 9 6 6}$ & & $\mathbf{1 1 . 8}$ \\
\hline
\end{tabular}

